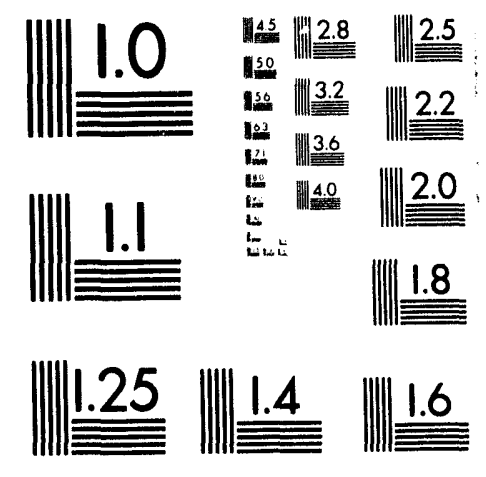



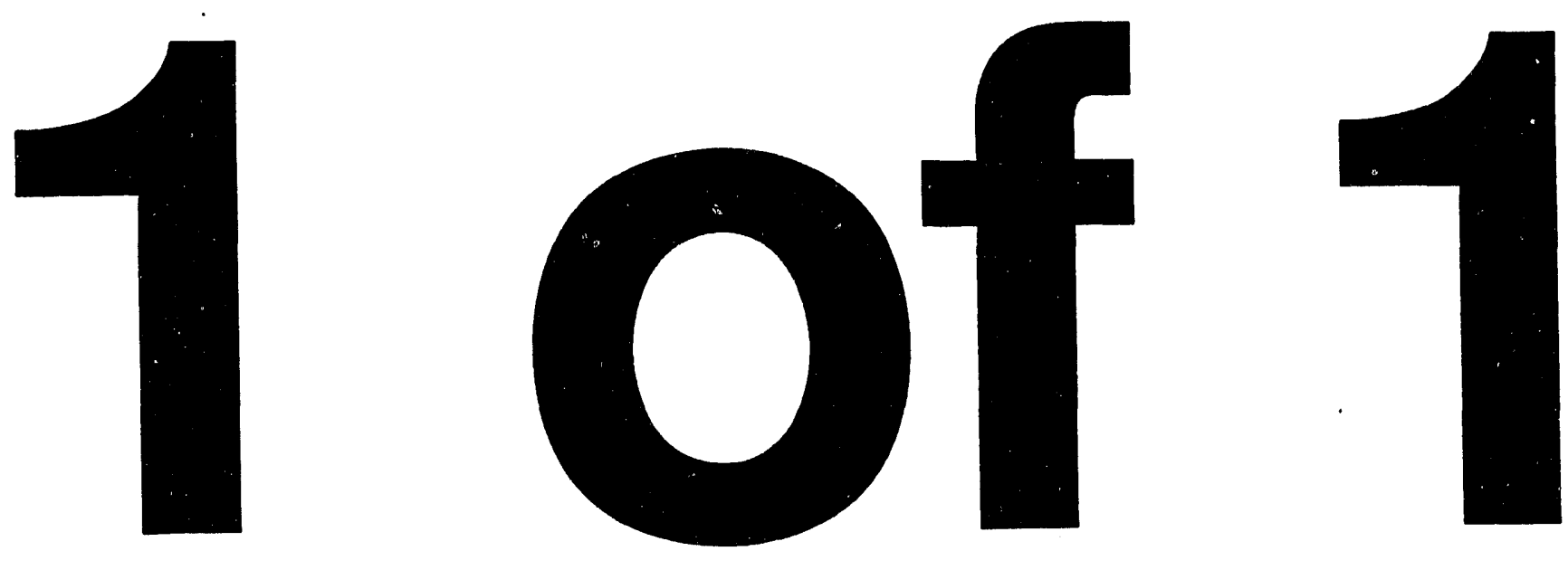


\section{SEPARATION PROJECTS WITHIN THE U.S. DEPARTMENT OF ENERGY'S UNDERGROUND STORAGE TANK-INTEGRATED DEMONSTRATION}

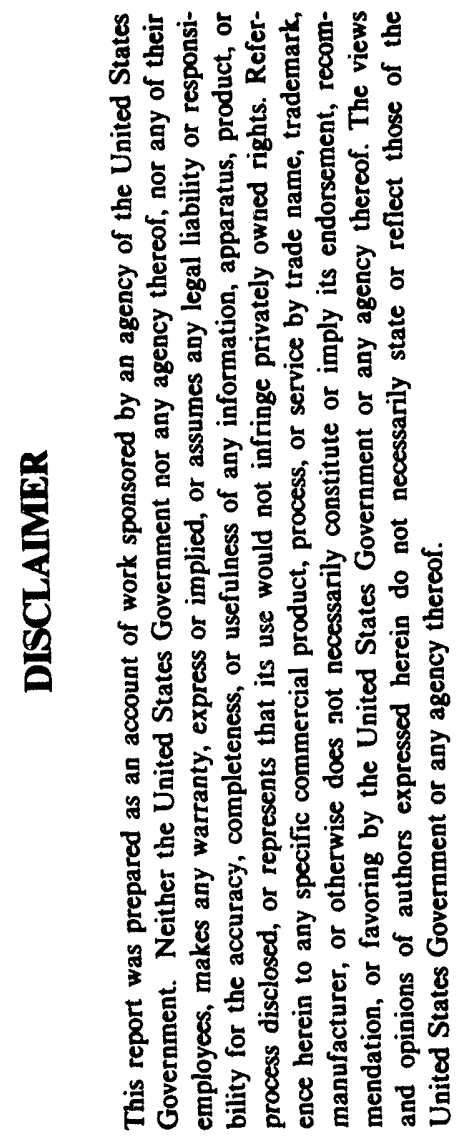

C. Phil McGinnis and Rodney D. Hunt*

Chemical Technology Division

Oak Ridge National Laboratory

Oak Ridge, Tennessee 37831-6273

Sherry M. Gibson

U.S. Department of Energy

12800 Middlebrook Road

Germantown, Maryland 20874

Roger L. Gilchrist

Westinghouse Hanford Corporation

P.O. Box 1970

Richland, Washington 99352

To be presented at the

Eighth Symposium on Separation Science and Technology

for Energy Applications

Gatlinburg, Tennessee

October 24-28, 1993

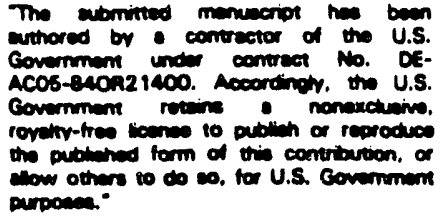

purpose.

"Managed by Martin Marietta Energy Systems, Inc., for the U.S. Department of Energy under contract DE-AC05-84OR21400

Condf.931043--3 


\title{
SEPARATION PROJECTS WITHIN THE U.S. DEPARTMENT OF ENERGY'S UNDERGROUND STORAGE TANK-INTEGRATED DEMONSTRATION
}

\author{
C. Phil McGinnis and Rodney D. Hunt \\ Chemical Technology Division \\ Oak Ridge National Laboratory \\ Oak Ridge, Tennessee $37831-6273$
}

\author{
Sherry M. Gibson \\ U.S. Department of Energy \\ 12800 Middlebronk Road \\ Germantown, Maryland 20874 \\ Roger L. Gilchrist \\ Westinghouse Hanford Corporation \\ P.O. Box 1970 \\ Richland, Washington 99352
}

\begin{abstract}
The greatest challenge facing the U.S. Department of Energy is the remediation of the $1 \times 10^{8}$ gal of high-level and low-level radioactive waste in the underground storage tanks (USTs) at its Hanford, Savannah River, Oak Ridge, Idaho, and Fernald sites. With current technologies, this remediation will cost at least 100 billion dollars. In an effort to reduce costs, improve safety, and minimize delays, the Underground Storage Tank-Integrated Demonstration was created for demonstration, testing, and evaluation (DT\&E) of promising new technologies that can be used
\end{abstract}


for UST remediation. These demonstrations, which are typically at the pilot-plant scale, will determine which processes will be used in the full-scale remediation of the USTs. These DT\&E studies are performed by the Characterization and Waste Retrieval Program or by the Waste Processing and Disposal Program (WPDP).

This paper presents the technical progress and future plans of the WPDP projects. The 11 WPDP programs in FY 1993 focused on three problem areas, which involve the treatment of supernate, the treatment of sludge, and nitrate destruction and subsequent waste forms. The three supernate projects were primarily concerned with the development of the compact processing units. The four sludge studies were designed to develop a complete system-level plan for handling sludge and supernate, with particular emphasis on sludge-dissolution treatment, and to evaluate TRUEX and diamide solvent extraction processes for transuranic waste streams. The four projects on nitrate destruction and subsequent waste forms approached these problems in unique ways. In addition, a planned Request for Expression of Interest on organic destruction techniques from private industries and universities and the WPDP's future direction and programmatic issues are discussed.

"Corresponding Author

\section{INTRODUCTION}

The production of nuclear materials has been the primary mission of the U.S. Department of Energy (DOE) and its predecessor agencies for the past 5 decades. The DOE production facilities and laboratories have generated a considerable amount of radioactive and mixed wastes.

Over $1 \times 10^{8}$ gal of waste are stored in 334 underground storage tanks (USTs) at Hanford, Savannah River, Oak Ridge, Idaho, and Fernald. The waste contains a wide variety of hazardous and nonhazardous chemical components such as sodium salts, acids, iron oxides, aluminum oxides, 
and heavy metals. Approximately half of the waste is composed of sodium nitrates and nitrites. The radionuclides are primarily transuranic (TRU) elements, ${ }^{137} \mathrm{Cs}$, and ${ }^{90} \mathrm{Sr}$. The temperatures of the waste range from near ambient to $93^{\circ} \mathrm{C}$, and some tanks occasionally contain potentially explosive gas mixtures. Tank void-space radiation can be as high as $10,000 \mathrm{rad} / \mathrm{h}$.

Due to the amount and variety of the nuclear waste, the remediation of the USTs is currently the greatest financial and technical challenge facing DOE. In response to these obstacles, DOE established the Office of Environmental Restoration and Waste Management (DOE-EM) in 1989. DOE-EM coordinates and manages the remediation, waste minimization, and environment compliances activities for the DOE sites. DOE-EM's Office of Technology Development (OTD) is responsible for providing new technologies which can reduce costs, improve safety, and minimize delays of the UST remediation. The OTD has divided the evolution of the new technologies into two phases: research and development (R\&D) and demonstration, testing and evaluation (DT\&E). The R\&D efforts are directed primarily by the Efficient Separations and Pretreatment-Integrated Program. After the new processes have completed their R\&D phases, the Underground Storage Tank-Integrated Demonstration (UST-ID) performs DT\&E on the most promising technologies. These UST-ID studies are performed by the Characterization and Waste Retrieval Program (CWRP) or by the Waste Processing and Disposal Program (WPDP). The results of these demonstrations will impact the selection of processes that will be used during the full-scale remediation of the USTs.

The WPDP has developed a strategic plan (1) with the assistance of the WPDP Steering Group, which is composed of senior advisors from several DOE laboratories. The WPDP strategic objectives are the following:

1. Demonstrate the removal of radionuclides and chemical toxicity from low-level waste (especially alkaline supernate processing). 
2. Demonstrate the removal of the constituents contributing to excess volume of high-level waste (HLW) from HLW sludges and acidic wastes.

3. Demonstrate technologies and strategies to maximize releasable or reusable fractions from the wastes.

4. Demonstrate technologies and strategies to minimize the requirements for pretreatment chernicals.

5. Develop improved waste forms to ensure compatibility of pretreated material with final waste forms.

This strategic plan serves as the basis for the projects managed by the WPDP.

\section{RESULTS AND DISCUSSION}

The accomplishments and future plans of the WPDP projects will be presented. These projects are separated into three areas: supernate processing, sludge processing, and nitrate destruction and final waste forms. In addition, a planned Request for Expression of Interest (REI) on organic destruction techniques from private industries and universities and the WPDP's future direction and programmatic issues are discussed.

\section{SUPERNATE PROCESSING}

Cesium-Extraction Compact Processing Unit (W. G. Richmond, Pacific Northwest Laboratory) A compact processing unit (CPU) is a transferable processing unit design to treat radioactive UST waste at a rate of 2 to $5 \mathrm{gal} / \mathrm{min}$. Therefore, the CPU (2) can deploy treatment technologies faster and more cheaply than the current baseline alternative, which is a large centralized shielded-canyon structure. This program is responsible for the design and construction 
of a CPU for the removal of cesium (Cs) from the UST waste. This CPU consists of four major subsystems: the containment system, the process system, the control system, and the process interface system. Due to the modular design of the CPU, the components can be fabricated offsite, and they can be reused in different processing units. The principal design criteria of the components for the Cs ion-exchange CPU are the following:

1. Capacity to process $1 \times 10^{6}$ gal of Hanford double-shell tank waste in 1 year.

2. Cs removal factor of $1 \times 10^{5}$.

3. Design that permits relocation using a construction crane and transport trailer.

4. Full compliance with all applicable federal and state regulations.

5. Capacity to operate without maintenance for a minimum of 1 year.

The cesium-removal CPU will treat undiluted supernate from a UST or liquid from a waste retrieval system. The CPU will filter this waste in order to remove the solids, which will be transferred into a holding tank for alternative processing. The filtered tank waste will be adjusted to optimum conditions for the ion-exchange process. The adjusted waste will then be pumped through three ion-exchange columns, which are in series, to remove the Cs from the waste. This cesium-free waste will be returned to the tank farm. The ion-exchange columns will probably use the resorcinol-formaldehyde resin (3-5) that was developed at the Savannah River Technology Center (SRTC). The cesium-loaded resorcinol-formaldehyde resin can be regenerated using nitric acid to the remove the Cs. The waste with the high Cs concentration will be neutralized and will become a waste feed stream for the vitrification process.

During FY 1994, this project will finalize the design of the CPU for Cs extraction, and it will begin to procure the ion-exchange and instrument and control subsystems. This program will also complete the design of the enclosure and tank farm interface. Preparations for the nonradioactive demonstration in FY 1996 will also be initiated. This project will continue to work 
closely with the Initial Pretreatment Module (IPM) project for the implementation and interface requirements.

\section{Cesium-Extraction Testing (J. P. Bibler, Westinghouse Savannah River Company)}

This project has performed three different types of-ion exchange experiments on the resorcinol-formaldehyde resin (3-5) at SRTC. These test results are critical to the successful deployment of the cesium-extraction CPU. This study has subjected the resin to ionizing radiation from a ${ }^{60} \mathrm{Co}$ source. The only hazardous or flammable compound that was produced by the irradiation of $1 \times 10^{9} \mathrm{rad}$ was hydrogen. The ability of the resin to maintain its selectivity and capacity in a highly radioactive environment was also evaluated. Another set of experiments used a simulated Hanford 101-AW waste to study the behavior of a small column of resin at various flow rates, $\mathrm{Na}^{+}$concentrations, and temperatures. These results were used to optimize the column behavior. Finally, elution studies of the resin after $\mathrm{Cs}^{+}$saturation have generated an elution profile which will be used to determine the most suitable elution medium, flow rate, and volume.

The main focus of this project during FY 1994 will be pilot-scale demonstration of the resorcinol-formaldehyde resin using the skid-mounted ion-exchange demonstration unit at SRTC. This study will determine if the resin can mect the CPU specifications. As part of the project's continued resin support, technical guidance for the resin-degradation study at Clark Atlanta University will be provided. Since the shelf life of the resin is only 3 to 5 years, the cause of the degradation must be determined in order to ensure proper storage.

\section{Tank Waste Analysis (N. G. Colton, Pacific Northwest Laboratory)}

This study has identified the most appropriate deployment scheme for the pretreatment of Hanford waste using the CPU distributed-processing approach. The spreadsheet and tank waste 
characterization data were used to determine specific processing requirements including decontamination factors for each tank. The spreadsheet uses decision trees that represent the processing logic of specific chemical approaches to pretreatment. The quantitative criteria for the target waste components for the Tank Waste Remediation System (TWRS) and the Clean Option scenarios are included in the spreadsheet. The results of this study were compiled in a database which is being distributed throughout DOE.

Another objective of this project was to develop schedules for the TWRS and Clean Option scenarios for the implementation of the distributed processing of the Hanford tank waste. A methodology was developed to identify the most rapid implementation strategy based on the availability of suitable technology. EM-30 has assumed responsibility for this project in FY 1994.

\section{SLUDGE PROCESSING}

Comprehensive Demonstration on Sludge/Supernate Processing (B. Z. Egan, Oak Ridge National Laboratory)

The primary mission of this demonstration is to develop the preferred sludge/supernate processing flowsheet. In addition, a realistic performance assessment for each individual process will be determined, and operating results which are needed for the pilot-plant design will be generated. This program will examine the separation of the solids, the washing of solids, the acid dissolution of the solids, the partitioning of the TRU components from the acid solutions, and the pretreatment of the supernate and soluble portions. Even though individual sludge processes are known to partition or destroy specific components, combinations of these processes have not been evaluated. Once the compatibilities of the various processes are known, the optimum combination will be determined based on cost and waste minimization. 
In order to perform realistic evaluations, approximately $5 \mathrm{~L}$ of actual sludge/supernate waste from the Melton Valley Storage Tanks at Oak Ridge National Laboratory (ORNL) were successfully transferred to a hot cell. Once the characterization of this waste is complete, benchscale batch tests of the individual processes that have been proposed for the integrated supernate and sludge processing flowsheets will be initiated. This demonstration is the first time that liter quantities of actual UST waste are being used for DT\&E of waste remediation technologies.

During FY 1994, the comprehensive sludge/supernate demonstration will evaluate the ability of resorcinol, $\mathrm{Na}_{2} \mathrm{CoFe}(\mathrm{CN})_{6}$, and $\mathrm{Na}_{2} \mathrm{TiO}_{3}$ to remove cesium and strontium from the supernate. The sludge-dissolution studies with nitric acid will also be completed. Bench-scale testing of TRUEX and partitioning of actinides will be initiated.

\section{TRUEX Model Development (G. F. Vandegriff, Argonne National Laboratory)}

Nuclear fuel reprocessing plant operations and plutonium production and purification processes generate significant quantities of aqueous nitrate and chloride which contain small amounts of TRU elements. The TRUEX process $(6,7)$, a solvent extraction procedure, was developed to separate the TRU components from these aqueous solutions. A successful separation reduces the amount of TRU waste which must be processed by the vitrification plant. Most of the resulting solutions from the TRUEX process can be disposed of as a low-level waste, which will greatly reduce the overall cost of final disposal.

The Argonne National Laboratory (ANL) staff (8) has developed the Generic TRUEX Model (GTM) as a tool for designing site- and feed-specific TRUEX flowsheets and for estimating the space and cost requirements for installing a TRUEX process. The GTM has been recently enhanced through improvements in the thermodynamic modeling and computer codes.

In FY 1994, ANL will compare the data from TRUEX studies by the Power Reactor and Nuclear Fuel Development Corporation of Japan and the Radiochemical Engineering 
Development Center (REDC) at ORNL with the predicted results from the GTM. ANL will also use the results from these pilot-plant-scale demonstrations to refine and validate the GTM.

\section{TRUEX Data Collection and Model Validation (L. K. Felker, Oak Ridge National Laboratory)}

The REDC at ORNL was selected to test the TRUEX process and to validate the GTM since REDC has extensive experience processing fuel elements to recover TRU elements. A TRUEX flowsheet has been developed with the assistance of ANL staff. A bank of continuous contactors known as the Solvent Extraction Test Facility was used for the TRUEX demonstration. A solution containing gram quantities of $\mathrm{Pu}, \mathrm{Am}$, and $\mathrm{Cm}$ from the dissolution of irradiated Mark 42 targets was used as the feed. During the demonstration, REDC personnel collected samples, which are being analyzed by the Analytical Chemistry Division at ORNL. This project represents the most extensive test of the TRUEX process and GTM.

During FY 1994, REDC personnel will perform an independent validation of the GTM by comparing the GTM predictions with the actual Mark 42 results. In addition, areas in the TRUEX process and the GTM which need changes or further study will be identified. A final report on these findings will be submitted in early 1994.

\section{Commissariat á l'Energie Atomique Interchange (R. T. Jubin, Oak Ridge National Laboratory)}

Numerous countries such as France, Japan, and England are funding projects for improving the chemical processes that are associated with the remediation of nuclear waste. These research activities are directed at reducing the amount and radiotoxicity of the waste. As a result of these efforts, several new technologies for the separation of specific radionuclides have been developed. It is in the national interest to expand our collaborative agreements with the major foreign organizations which are examining nuclear waste remediation. In particular, the 
Commissariat á l'Energie Atomique Interchange (CEA) is prime candidate for a collaboration due to its long-term development program on the separation of long-lived radionuclides.

Technical interchange includes the placement of an ORNL staff member at the CEA in early FY 1994, and it will initially focus on the French ACTINEX process, which uses diamides as the extractants for the actinides. The ACTINEX process will be evaluated against comparable DOE technology, which includes the TRUEX process. During the course of the interchange, technical collaborations in other specific areas will be explored. In addition, the ORNL staff member assigned to CEA will develop a broad understanding of French waste management as a whole.

\section{NITRATE DESTRUCTION/FINAL WASTE FORMS}

\section{Nitrate to Ammonia and Ceramic Process (A. J. Mattus, Oak Ridge National Laboratory)}

Bench-scale feasibility studies (9) using Hanford and Oak Ridge tank waste simulants have demonstrated that a new low-temperature $\left(50-90^{\circ} \mathrm{C}\right)$ process can convert 90 to $99 \%$ of the nitrate to ammonia. In the nitrate to ammonia and ceramic (NAC) process, aluminum powders or shot was used to convert alkaline, nitrate-based supernate to ammonia and an alumina-silica-based ceramic solid. The final nitrate-free ceramic product was then calcined, pressed, and sintered. Volume reductions as high as $70 \%$ were obtained for the final waste form in the NAC process. In sharp contrast, grouting will lead to volume increases of 40 to $50 \%$.

Reaction rates from the feasibility study were calculated to approximate the rate in a pilot plant. The rates were based on a differential nitrate reduction at a point in the reaction where the nitrate is actively reduced. Since the cost of aluminum is a major part of the overall cost, maximizing reaction efficiency is essential. This conversion process may be the ideal way to utilize and dispose of already contaminated scrap aluminum metal from the gaseous diffusion plant. 
The NAC project is currently examining waste-form properties such as leaching resistance for sodium. The major emphasis in FY 1994 will involve the design, construction, and testing of a NAC pilot plant at ORNL. In addition, Florida International University will be optimizing microwave processes for the drying, calcining, and sintering of the NAC ceramic product into a final waste form.

Calcination/Dissolution Process Development (S. A. Colby, Westinghouse Hanford Company) A series of full-scale tests (10) at the Westinghouse Science and Technology Center has demonstrated the feasibility of plasma-arc technology to calcine simulated Hanford tank waste. The primary objective of these trials was to identify the combination of chemical dissolution and thermal processing that will destroy nitrates, organics, and ferrocyanides. A major benefit of the plasma-arc process is the separation of the TRU waste into a relatively small volume.

Other support activities involved mass balances, simulant preparation, and residue leaching development. A chemical analysis was conducted to verify and optimize the process parameters and to improve the material balances and the simulant preparation. The residue leaching task determined the additional treatment techniques that are needed to further concentrate the TRU residue after the calcination step. In addition, the chemical dynamics of the calcination and dissolution process steps were evaluated. Since this project has successfully completed its demonstration phase and has been selected as a reference process for the IPM, the IPM project is funding this project for FY 1994.

Biological Destruction of Tank Wastes (G. F. Andrews, Idaho National Engineering Laboratory)

This project adapts existing biotechnology processes for use in the denitrification of nitrate salts from the USTs. Another objective of this program involves the separation and concentration of the metals for safe final disposal in a radioactive repository. This project has focused on a 
mixed culture of nature bacteria that were isolated from the Great Salt Lake and Death Valley. The bacteria are able to grow and reduce nitrate in the very high salt concentrations that are found in the tank wastes. After the bacteria are grown in a bioreactor, they are mixed with the waste in a biosorption tank. Even though the bacteria in this tank may be killed, dead and living bacteria biosorb the metals to the same extent. Filtration of the tank generates a biomass sludge waste that contains the metals and the radioactivity. The liquid which contains nitrate and very low levels of metals, and is transferred into the bioreactor. Acetic acid is added as a carbon source for the bacterial growth. The bacteria reduces the nitrate to innocuous nitrogen gas that is filtered and released to the atmosphere. Even though remaining metals are adsorbed by the growing bacteria, the metal concentrations are too low to inhibit the bacterial metabolism. After filtration, the effluent of the bioreactor is a low-radioactive, nonhazardous salt solution suitable for wastewater treatment.

This project in FY 1994 will complete the evaluation of the metal/radionuclide biosorption capabilities. In addition, this project will develop, design, construct, and operate a large laboratory-scale unit to test and evaluate this technology using simulated tank waste. The information that is generated from this demonstration will be used to design a CPU for installation at the Hanford site. Size and cost estimates for the CPU will be made.

\section{Polyethylene Encapsulation (P. D. Kalb, Brookhaven National Laboratory)}

Polyethylene encapsulation (11) has been successfully applied to the treatment of lowlevel wastes. Since polyethylene is an inert thermoplastic with a processing temperature of approximately $150^{\circ} \mathrm{C}$, it is not susceptible to chemical interactions between the waste and binder that can adversely affect the solidification. This factor makes processing less dependent on the chemistry of the waste. This process can encapsulate more waste per unit volume than the current baseline technology, cement-based grout. 
Extensive testing of polyethylene's waste-form performance, which is superior to that of cement grout, was completed. Polyethylene's compressive strength, water immersion, thermal cycling, radioactive and hazardous constituent leachability, radiation stability, and biodegradation easily exceeded the regulatory criteria. The WPDP cofunding of this project was concluded at the end of FY 1993 since polyethylene sncapsulation of nitrate salt waste was not selected for a production-scale technology demonstration.

\section{Alternative Organic Destruction Processes (R. D. Hunt, Oak Ridge National Laboratory)}

The current IPM baseline technologies for organic destruction are calcination with a plasma arc and supercritical water oxidation. The UST-ID has identified a need to examine alternative technologies for organic destruction. The WPDP manager has chosen an evaluation committee which is composed of technical and procurement experts. After the committee has set the criteria for the organic destruction technologies, an REI announcement will be submitted to the Commerce Business Daily in early FY 1994. After the responses have been received and evaluated, the committee will issue a report with recommendations to the UST-ID.

\section{Waste Processing and Disposal Program (C. P. McGinnis, Oak Ridge National Laboratory)}

The UST-ID is one of several of national demonstrations designed to consolidate a multiple-site approach to the development of technology to solve specific DOE-EM needs. The UST-ID is composed of the WPDP and CWRP. This organizational structure permits critical issues of waste processing and disposal (WPD) to receive full and prompt attention by the appropriate separation scientists and engineers. Currently, the WPDP is coordinating eight separate development programs with five different contractors. The responsibilities of the WPDP include evaluating proposals, preparing strategic and program management plans $(1,12)$, answering inquiries from the Integrated Demonstration Coordinator (IDC) and from DOE-EM at 
headquarters, and representing the IDC and the DOE in the areas of WPD as necessary. The WPDP will continue to perform these functions until these new technologies meet their technical objectives, receive regulatory and stakeholder acceptance, and are deployed for the remediation of UST wastes.

\section{CONCLUSIONS}

The greatest technical and financial challenge facing DOE is the remediation of the USTs. In an effort to reduce remediation costs, improve safety, and minimize delays, the WPDP has been conducting DT\&E on new separation and treatment technologies. The WPDP projects for FY 1993 examined supernate and sludge treatment, nitrate destruction, and subsequent waste forms. The supernate projects were primarily concerned with the development of the Cs-extraction CPU. The objectives of the sludge studies were to develop a complete system-level plan for handling sludge/supernate and to evaluate TRUEX and diamide solvent extraction processes for TRU waste streams. The projects on nitrate destruction and subsequent waste forms include the calcination/dissolution process, polyethylene encapsulation, biodenitrification, and the NAC process. The results of the WPDP projects will impact the selection of the processes that will be used in the full-scale remediation of the USTs.

\section{ACKNOWLEDGEMENTS}

The WPDP and its projects are sponsored by the Underground Storage Tank-Integrated Demonstration, which is funded by DOE's Office of Technology Development. The authors gratefully acknowledge the contributions from the principal investigators as well as their technical program management. 


\section{REFERENCES}

1. C. P. McGinnis, Strategic Plan for the Waste Processing and Disposal Program of the Underground Storage Tank-Integrated Demonstration, Report ORNL/M-3083, Oak Ridge National Laboratory, Oak Ridge, Tennessee, 1993.

2. J. W. Bailey, Engineering Study-Initial Pretreatment Module W-236B, Report WHC-SD-W236B-ES-001, Westinghouse Hanford Company, Richland, Washington, 1992.

3. J. P. Bibler, R. M. Wallace, and L. A. Bray, Testing a New Cesium-Specific Ion Exchange Resin Decontamination of Alkaline High-Activity Waste, in Proceedings of Waste Management '90, Vol. 2, 1992, p.747.

4. J. P. Bibler and R. M. Wallace, Preparation and Properties of a Cesium-Specific Resorcinol-Formaldehyde Ion Exchange Resin, Report DPST-87-647, Savannah River Laboratory, Aiken, South Carolina, 1987.

5. D. O. Campbell, D. D. Lee, and T. A. Dillow, Low-Level Liquid Waste Decontamination by Ion Exchange, Report ORNL/TM-11789, Oak Ridge National Laboratory, Oak Ridge, Tennessee, 1990.

6. M. C. Regalbuto, B. Misra, D. B. Chamberlain, R. A. Leonard, and G. F. Vandegrift, The Monitoring and Control of TRUEX Processes, Volume One-The Use of Sensitivity Analysis to Determine Key Process Variables and Their Control Bound, Report ANL-92-7, Argonne National Laboratory, Argonne, Illinois, 1992.

7. R. A. Leonard, G. F. Vandegriff, D. B. Chamberlain, D. J. Chaiko, D. R. Fredrickson, J. E. Stangel, L. Burris, E. P. Horwitz, R. C. Gatrone, K. L. Nash, and P. G. Rickert, The TRUEX Process for Recovery of Plutonium and Americium from Nitric Acid Waste Solutions-Final Report, Report ANL-90-6, Argonne National Laboratory, Argonne, Illinois, 1990. 
8. G. F. Vandegriff, J. M. Copple, D. B. Chamberlain, R. A. Leonard, M. C. Regalbuto, D. J. Chaiko, L. Chow, D. R. Fredrickson, R. J. Jaskot, L. Nunez, J. Sedlet, I. R. Tasker, L. E. Trevorrow, and E. H. VanDeventer, The Generic TRUEX Model-Operating Manual for the IBM-PC Compatible and Macintosh Computers, Report ANL-92-41, Argonne National Laboratory, Argonne, Illinois, 1992.

9. A. J. Mattus, D. D. Lee, T. A. Dillow, L. L. Farr, S. L. Loghry, W. W. Pitt, and M. R. Gibson, A Low-Temperature Process for the Denitration of Hanford Single-Shell Tank, Nitrate-Based Waste Utilizing the Nitrate to Ammonia and Ceramic (NAC) Process, Report ORNL/TM-12245, Oak Ridge National Laboratory, Oak Ridge, Tennessee, 1992.

10. W. R. Gass, S. V. Dighe, and D. F. McLaughlin, Plasma Calcination of Simulated HighLevel Nuclear Waste, STC Report 93-9T03-CALCI-R1, Westinghouse Science and Technology Center, Pittsburg, Pennsylvania, 1993.

11. P. D. Kalb, J. H. Heiser III, and P. Colombo, Polyethylene Encapsulation of Nitrate Salt Wastes: Waste Form Stability, Process Scale-up, and Economics, Technology Status Topical Report, Report BNL-52293, Brookhaven National Laboratory, Upton, New York, 1991.

12. C. P. McGinnis, Project Management Plan for Separations and Pretreatment Studies, Report ORNL/M-3082, Oak Ridge National Laboratory, Oak Ridge, Tennessee, 1993. 


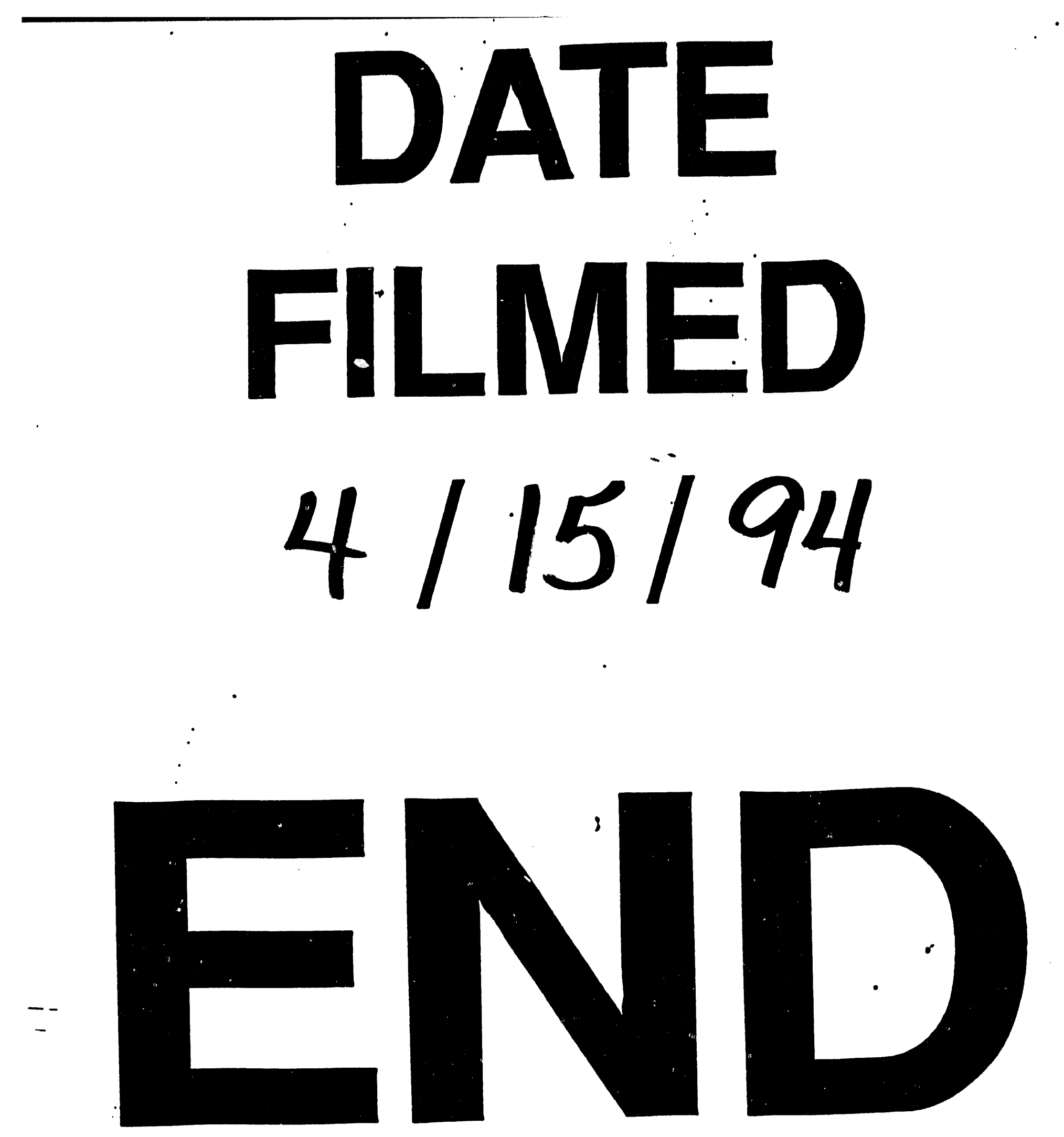




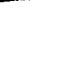

